\title{
Kinetics of Protein Turnover in Growing Cells of Bacillus megaterium
}

\author{
By J. CHALOUPKA* AND M. STRNADOVÁ \\ Institute of Microbiology, Department of Cell Physiology, Czechoslovak Academy of \\ Sciences, 14220 Prague 4, Czechoslovakia
}

(Received 17 June 1981; revised 8 September 1981)

The course of protein degradation during growth of a $\left[{ }^{14} \mathrm{C}\right]$ leucine-labelled population of Bacillus megaterium with a surplus of the non-radioactive amino acid indicated the presence of a labile protein fraction decaying with a half-life of less than $1 \mathrm{~h}$. The half-life of the remaining 'stable' fraction was much longer ( $40 \mathrm{~h}$ or more). A nutrient shift-down increased, and a shift-up decreased the relative size of the labile fraction and the rate of degradation of the 'stable' fraction. When bacteria were prelabelled in the presence of ethionine, both the size of the labile fraction and the rate of degradation of the 'stable' fraction were increased. A shift-up in temperature caused a large increase in the size of the labile fraction while the rate of degradation of 'stable' proteins increased only slightly. The rate of degradation of the labile fraction was not changed significantly by any treatment. The results suggest that the main target of regulation of protein turnover by environmental conditions is the relative size of the labile protein fraction.

\section{INTRODUCTION}

Partial or complete degradation of protein molecules in growing bacterial populations appears to play a role primarily in protein processing or the removal of abnormal proteins, such as the products of translational errors. The half-lives of such processes are probably no longer than several minutes (Pine, 1970; Goldberg, 1972; Bukhari \& Zipser, 1973). In a special case, the germination of spores of bacilli, the labile protein fraction is formed by several kinds of proteins, synthesized during sporogenesis; their degradation supplies the germinated spore with amino acids making possible a rapid onset of protein synthesis (Setlow, 1975). However, most proteins in growing bacteria are relatively stable and their degradation rates do not usually exceed $1 \% \mathrm{~h}^{-1}$ (Goldberg \& St John, 1976).

The general rate of protein turnover in Escherichia coli is regulated by nutrition as well as by temperature (Pine, 1973). These conclusions were derived mostly from experiments in which the turnover rate was calculated from samples taken at one or two time intervals. Our study of protein turnover in Bacillus megaterium is based on the measurement of the kinetics of protein degradation, from which the proportions of the labile and 'stable' fractions and their degradation constants could be separately determined. We found that the size of the labile fraction, with a half-life of less than $1 \mathrm{~h}$, and to a lesser extent the degradation rate of the 'stable' fraction, are influenced by cultivation conditions.

\section{METHODS}

The asporogenous strain of Bacillus megaterium $\mathrm{KM}$, and the composition of mineral $\mathrm{C}$ medium were described previously (Chaloupka et al., 1975). The medium was supplemented with glucose $\left(5 \mathrm{mg} \mathrm{ml}^{-1}\right)$. When the influence of different media was studied, either $\mathrm{NH}_{4} \mathrm{Cl}$ was omitted and replaced with DL-leucine $(5 \mathrm{mM})$ as the sole nitrogen source $(C-N+L)$, or casein hydrolysate (Oxoid; $10 \mathrm{mg} \mathrm{ml}^{-1}$ ) was added $(C+A A)$. The media were supplemented with DL-leucine $(+\mathrm{L} ; 5 \mathrm{mM})$ or DL-valine $(+\mathrm{V} ; 5 \mathrm{~mm})$ when measuring protein turnover, in order to 
prevent the re-utilization of the ${ }^{14} \mathrm{C}$-labelled amino acid released from prelabelled cells. The exchange of external and internal leucine was very rapid (Váchová-Philippová et al., 1980).

The cultures were grown in Erlenmeyer flasks, shaken in a water bath $\left(100\right.$ strokes $\left.\min ^{-1}\right)$ at $35^{\circ} \mathrm{C}$, unless stated otherwise. Growth was followed by measuring turbidity $\left(A_{650}\right)$.

The cells were labelled with $\mathrm{L}-\left[\mathrm{U}-{ }^{14} \mathrm{C}\right]$ leucine, or $\mathrm{L}-\left[\mathrm{U}^{-14} \mathrm{C}\right]$ valine [ÚVVVR, Prague; $0.2 \mu \mathrm{Ci} \mathrm{ml}{ }^{-1}$ $\left(7.4 \mathrm{kBq} \mathrm{ml}^{-1}\right) ; 10 \mu \mathrm{M}$ ] during growth in $\mathrm{C}$ medium. The labelling time was $2 \mathrm{~h}$; the cells were then collected by centrifugation and resuspended in the appropriate medium. Degradation of proteins was followed by the release of radioactivity on treatment with hot $5 \%(\mathrm{w} / \mathrm{v})$ trichloroacetic acid (TCA). Samples were taken at 10-20 min intervals and added to one-third of their volume of $20 \%$ TCA containing $5 \mathrm{~mm}$ non-labelled leucine. After heating $\left(90^{\circ} \mathrm{C}, 20 \mathrm{~min}\right.$ ), the samples were centrifuged and the radioactivity in $0.5 \mathrm{ml}$ of the supernatant was determined in $5.0 \mathrm{ml}$ of Bray's scintillation solution in a Beckman LS 9000 liquid scintillation counter. The radioactivity (d.p.m.) in the TCA supernatant was subtracted from that in the TCA-insoluble fraction (taken as protein) at zero time. About $5 \%$ of the radioactivity was released from cells by hot $5 \%$ TCA at zero time (mostly due to free amino acids and amino acids adsorbed on teichoic acids). No radioactivity was extracted by lipid solvents. More than $90 \%$ of the radioactivity in the protein fraction was found to be $\left[{ }^{14} \mathrm{C}\right]$ leucine after total hydrolysis and thin-layer chromatography. The radioactivity present in $0.5 \mathrm{ml}$ of the protein fraction at zero time was about 10000 d.p.m. in most experiments.

The decrease in radioactivity was plotted as $\log (1-d)$ against time, where $d$ is the proportion of proteins degraded during the respective time interval. The slope of the 'linear' part of the curve indicates the degradation constant $\left(a_{2}\right)$ of the relatively stable protein fraction (designated the 'stable' fraction), and its intercept on the ordinate axis is equal to $\log \left(1-d_{0}^{\prime}\right)$, where $d_{0}^{\prime}$ is the proportion of the labile fraction at zero time. Its degradation constant $\left(a_{1}\right)$ was derived from the plot of $\log \left(d^{\prime}-d\right)$ against time. The value $\left(d^{\prime}-d\right)$ indicates the difference between the total amount of labelled protein remaining $(1-d)$ and the amount of the 'stable' fraction $\left(1-d^{\prime}\right)$ at any given time. The value $\left(1-d^{\prime}\right)$ was derived from the proportion of the 'stable' protein fraction at zero time $(1-$ $d_{0}^{\prime}$ ) and the degradation constant $a_{2}$. The degradation constants $a_{1}$ and $a_{2}$ are expressed as the proportion of the respective fraction of proteins degraded per hour. As the size of the labile fraction $(L)$ and the degradation constant $a_{2}$ are influenced by the length of the labelling time and the composition of the labelling medium, they have only a relative value.

The data obtained in three to six experiments were used for the construction of the curves. Five to eight points were used for the calculation of the slope. The slopes were calculated by linear regression; values of the regression coefficient $\left(r^{2}\right)$ are shown in the tables.

Autoproteolysis of cellular proteins in vitro was determined in protoplast lysates prepared from a culture prelabelled with $\left[{ }^{14} \mathrm{C}\right]$ leucine during growth in $\mathrm{C}$ medium. Protoplasts were formed using lysozyme $\left(0.2 \mathrm{mg} \mathrm{ml} \mathrm{m}^{-1}\right)$ treatment of cells in $0.1 \mathrm{M}$-Tris/ $\mathrm{HCl}$ buffer $(\mathrm{pH} \mathrm{7.2)}$, supplemented with $0.35 \mathrm{M}$-sucrose and tetracycline $\left(50 \mu \mathrm{g} \mathrm{ml}^{-1}\right)$. The incubation was at $35^{\circ} \mathrm{C}$ for up to $30 \mathrm{~min}$ and the formation of protoplasts was checked microscopically. Protoplasts collected by centrifugation were homogenized in $0.1 \mathrm{M}$-Tris/ $\mathrm{HCl}$ buffer $(\mathrm{pH} \mathrm{7.2)}$ containing $1 \mathrm{mM}-\mathrm{CaCl}_{2}$ by means of a Corning Pyrex piston homogenizer. Lysis was checked by phase-contrast microscopy. The lysates were incubated at different temperatures for $3 \mathrm{~h}$ and the increase in the $5 \%$ TCA-soluble radioactivity was determined.

\section{RESULTS AND DISCUSSION}

Growth rate was regulated by the composition of the medium as well as by temperature. In the former case, leucine $(\mathrm{C}-\mathrm{N}+\mathrm{L})$, ammonia $(\mathrm{C}+\mathrm{L})$ and amino acids $(\mathrm{C}+\mathrm{AA}+\mathrm{L})$ were used as nitrogen sources. With leucine as the nitrogen source, cultures grown and labelled in $\mathrm{C}$ medium, or in $\mathrm{C}-\mathrm{N}+\mathrm{L}$ medium (adapted culture), were used for the analysis of protein turnover. The leucine-adapted culture was labelled with $\left[{ }^{14} \mathrm{C}\right]$ valine, and the others with $\left[{ }^{14} \mathrm{C}\right]$ leucine. Because of the relatively long period of labelling $(2 \mathrm{~h})$, there was no preferential labelling of short-lived proteins.

When the generation time was increased, there was a parallel increase in the total amount of protein degraded. The non-adapted culture (mass doubling time $6.8 \mathrm{~h}$ ) replaced $14.0 \%$ of protein in $3 \mathrm{~h}$ growth in $\mathrm{C}-\mathrm{N}+\mathrm{L}$ medium, the adapted culture (mass doubling time $2.7 \mathrm{~h}$ ) replaced $8.5 \%$, the culture growing in $\mathrm{C}+\mathrm{L}$ medium (mass doubling time $1.6 \mathrm{~h}$ ) replaced $4.6 \%$ of protein, and the culture after shift-up to $\mathrm{C}+\mathrm{AA}+\mathrm{L}$ medium (mass doubling time $1.0 \mathrm{~h}$ ) replaced $3.1 \%$ of protein. For comparison, a culture starving in $\mathrm{C}-\mathrm{G}+\mathrm{L}$ medium (C medium without glucose) degraded $12.1 \%$ of protein in $3 \mathrm{~h}$. The results are similar to that of Pine (1973) obtained with Escherichia coli, but analysis of the course of degradation 


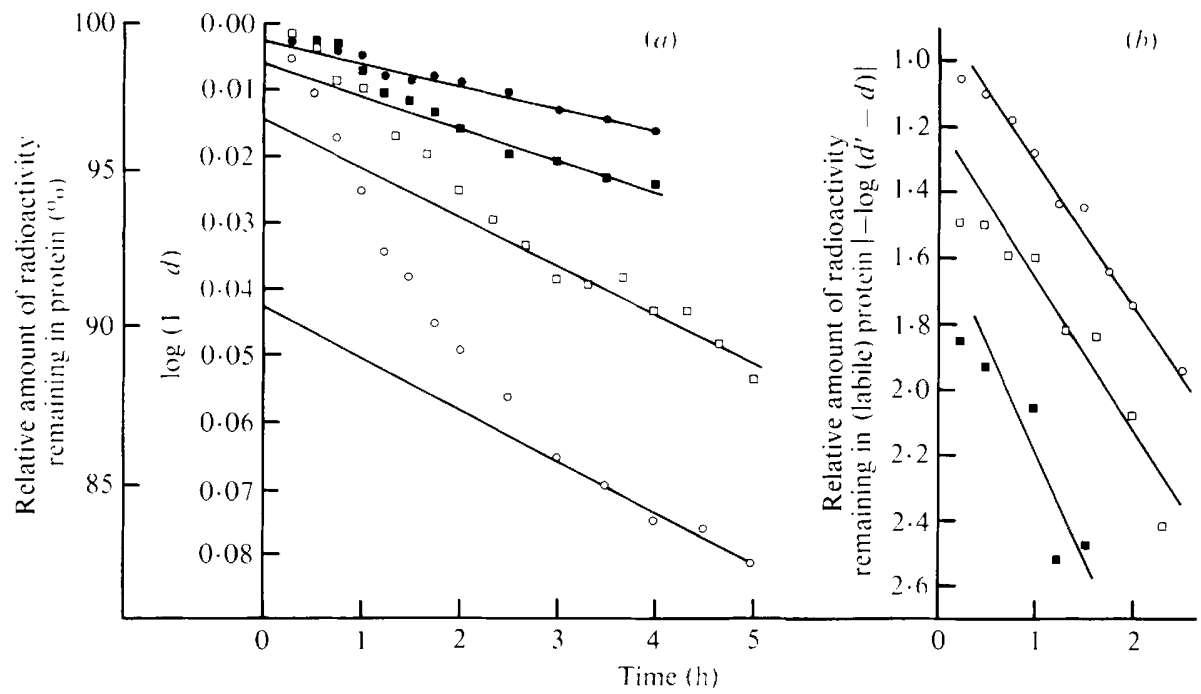

Fig. 1. Protein turnover during growth in different media. Culture labelled in $\mathrm{C}$ medium was transferred to $\mathrm{C}-\mathrm{N}+\mathrm{L}(\mathrm{O}), \mathrm{C}+\mathrm{L}(\mathbf{0})$ or $\mathrm{C}+\mathrm{AA}+\mathrm{L}(\mathbf{O})$ medium. Culture labelled in $\mathrm{C}-\mathrm{N}+\mathrm{L}$ medium was transferred to $\mathrm{C}-\mathrm{N}+\mathrm{L}+\mathrm{V}(\square)$ medium. (a) Kinetics of degradation of total protein. (b) Degradation of the labile fraction. (For details, see Methods.)

\section{Table 1. Size of the labile protein fraction and the degradation constants of the labile and 'stable' fractions for cells in different media}

$L$ is the size of the labile fraction (the values have been corrected for the onset of turnover - see Methods), $r^{2}$ is the regression coefficient, $a_{1}$ and $a_{2}$ are the degradation constants of the labile and 'stable' fractions, respectively, and $t_{\frac{1}{2}}$ is the half-life of protein. Data are taken from Fig. 1, except for protein turnover during starvation for glucose (presented for comparison).

\begin{tabular}{ccccccccc}
\multicolumn{1}{c}{ Medium } & $\begin{array}{c}\text { Mass } \\
\text { doubling } \\
\text { time (h) }\end{array}$ & $\overbrace{L(\%)}$ & $a_{1}\left(\mathrm{~h}^{-1}\right)$ & $r^{2}$ & $t_{\frac{1}{2}}(\mathrm{~h})$ & $\overbrace{a_{2}\left(\mathrm{~h}^{-1}\right)}^{\text {Labile fraction }}$ & $r^{2}$ & $t_{\frac{1}{2}}(\mathrm{~h})$ \\
$\mathrm{C}-\mathrm{G}+\mathrm{L}$ & No growth & 8.2 & 1.2 & 0.95 & 0.58 & $1.6 \times 10^{-2}$ & 0.85 & 43 \\
$\mathrm{C}-\mathrm{N}+\mathrm{L}$ & 6.8 & 9.5 & 1.0 & 0.99 & 0.69 & $1.8 \times 10^{-2}$ & 0.99 & 39 \\
$\mathrm{C}-\mathrm{N}+\mathrm{L}+\mathrm{V}$ & 2.7 & 3.5 & 1.1 & 0.91 & 0.63 & $1.7 \times 10^{-2}$ & 0.90 & 41 \\
$\mathrm{C}+\mathrm{L}$ & 1.6 & 1.5 & 1.3 & 0.86 & 0.53 & $1.1 \times 10^{-2}$ & 0.97 & 63 \\
$\mathrm{C}+\mathrm{AA}+\mathrm{L}$ & 1.0 & 0.7 & ND & & & $0.7 \times 10^{-2}$ & 0.96 & 99
\end{tabular}

ND, Not determined.

showed that the cell protein was composed of at least two major fractions: the labile fraction, decaying with a half-life of less than $1 \mathrm{~h}$, and the relatively stable fraction, with a half-life of $40 \mathrm{~h}$ or more (Fig. 1, Table 1). The size of the labile fraction was influenced most by regulatory changes, and the degradation of this fraction was responsible for a major proportion of overall protein turnover. The rate of degradation of the 'stable' protein fraction was regulated by the composition of the medium only in rapidly growing cultures and no significant differences in $a_{2}$ were found between cultures growing with generation times of $2.7 \mathrm{~h}, 6.8 \mathrm{~h}$ and the non-growing culture. The degradation constant of the labile fraction was probably independent of the growth rate in all the media tested.

The size of the pool of labile proteins in B. megaterium and their average half-life are similar to those of $E$. coli as found by Nath \& Koch (1970) by a different method. However, the remaining proteins in growing $E$. coli are essentially stable, whereas in $B$. megaterium they decay at finite rates controlled by the culture conditions. 


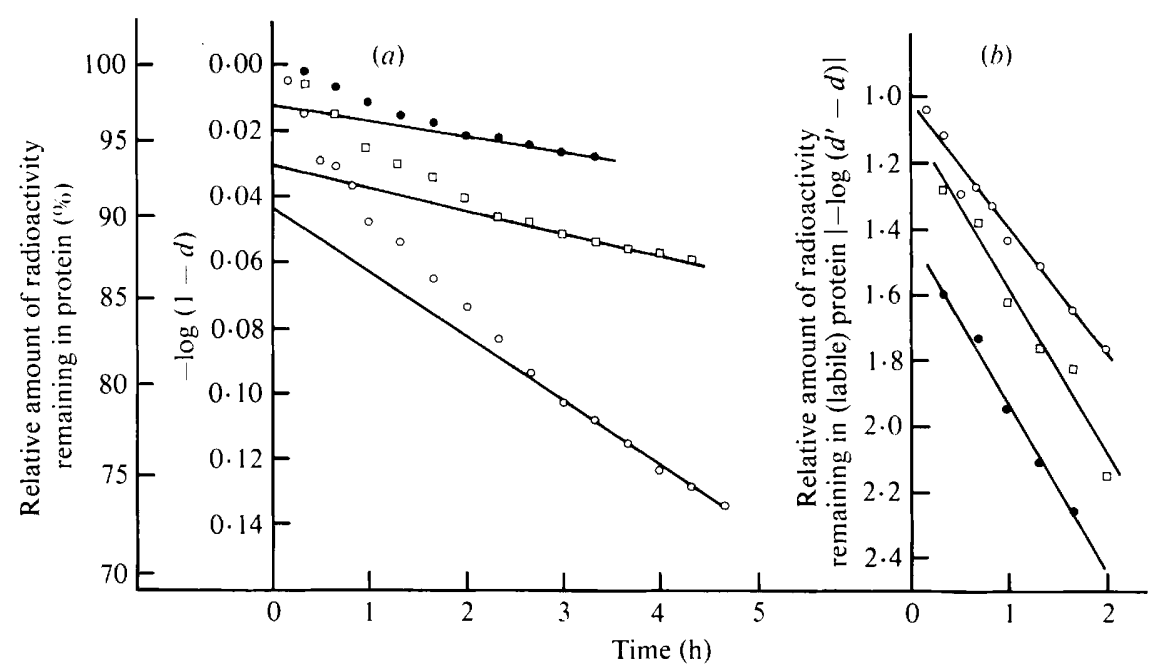

Fig. 2. Protein turnover in cells labelled in the presence of ethionine. Culture labelled in $\mathrm{C}$ medium with ethionine (5 mM) was transferred to $C-N+L(O), C+L(\square)$ or $C+A A+L(O)$ medium, all supplemented with methionine. (a) Kinetics of degradation of total protein. (b) Degradation of the labile fraction.

Table 2. Size of the labile protein fraction and the degradation constants of the labile and 'stable' fractions in cells labelled in the presence of ethionine

The symbols are defined in Table 1. The data are taken from Fig. 2.

\begin{tabular}{lccccccccc}
\multicolumn{1}{c}{$\begin{array}{c}\text { Mass } \\
\text { Medium }\end{array}$} & $\begin{array}{c}\text { Labling } \\
\text { time }(\mathrm{h})\end{array}$ & $\overbrace{L(\%)}^{\text {Labile fraction }}$ & $a_{1}\left(\mathrm{~h}^{-1}\right)$ & $r^{2}$ & $t_{\frac{1}{2}}(\mathrm{~h})$ & $\overbrace{a_{2}\left(\mathrm{~h}^{-1}\right)}^{\text {'Stable' fraction }}$ & $r^{2}$ & $t_{\frac{1}{2}}(\mathrm{~h})$ \\
$\mathrm{C}-\mathrm{N}+\mathrm{L}$ & 7.5 & 9.9 & 0.9 & 0.97 & 0.77 & $5.0 \times 10^{-2}$ & 0.99 & 14 \\
$\mathrm{C}+\mathrm{L}$ & 1.9 & 6.7 & 1.2 & 0.97 & 0.58 & $1.7 \times 10^{-2}$ & 0.99 & 41 \\
$\mathrm{C}+\mathrm{AA}+\mathrm{L}$ & 1.0 & 3.0 & 1.2 & 0.99 & 0.58 & $1.1 \times 10^{-2}$ & 0.96 & 63
\end{tabular}

When bacteria were labelled in the presence of ethionine (an analogue of methionine), exponential growth resumed only after a delay of 30-45 min following transfer of such a culture to fresh medium supplemented with methionine. Also the growth rate of an ethionine-pretreated population was slightly lower than in the control culture. The size of the labile protein fraction and the degradation constant of the 'stable' fraction were substantially increased (Fig. 2, Table 2). The degradation constant of the labile fraction remained unchanged. Ethionine can partially replace methionine in proteins (Yoshida \& Yamasaki, 1959). The increased degradation constant of the 'stable' proteins might thus indicate that at least some abnormal proteins are not always degraded as part of the labile protein fraction.

Increased temperature increased both the growth rate and the extent of protein turnover (Fig. 3, Table 3). The increase in the size of the labile fraction with increase in temperature is more than could be explained by its effect on proteolytic activity alone. However, the changes in the degradation constant of the 'stable' fraction (compare $a_{2}$ at $28{ }^{\circ} \mathrm{C}$ and $35^{\circ} \mathrm{C}$ ) could result from an increase in activity of proteolytic enzymes at the higher temperature. The relatively low $a_{2}$ at $42{ }^{\circ} \mathrm{C}$ is possibly due to a decrease in sensitive proteins in the stable fraction. The virtual lack of stimulation of the degradation rate of the labile protein fraction by increased temperature could result from a concomitant increase of heterogeneity in this fraction. 


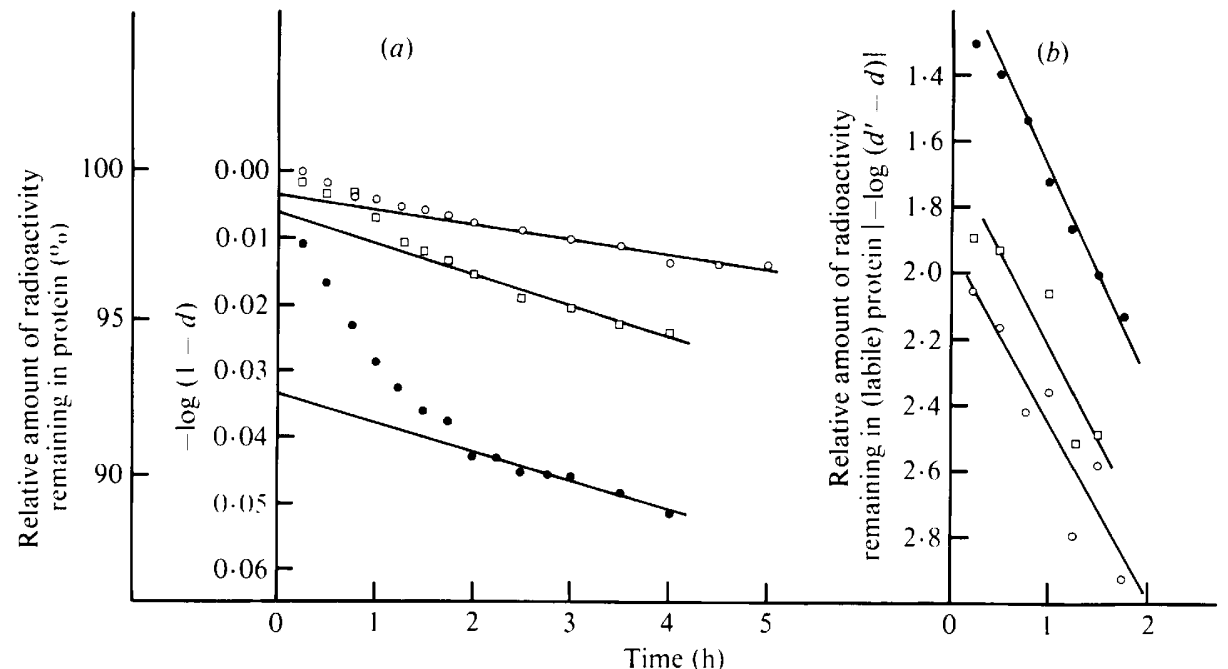

Fig. 3. Influence of temperature on protein turnover. Culture labelled in $\mathrm{C}$ medium at $28^{\circ} \mathrm{C}$ was transferred to $\mathrm{C}+\mathrm{L}$ medium and incubated at $28^{\circ} \mathrm{C}(\mathrm{O})$ or $42{ }^{\circ} \mathrm{C}(\mathrm{O})$. Culture labelled at $35^{\circ} \mathrm{C}$ was incubated at $35^{\circ} \mathrm{C} \mathrm{( \square )} \mathrm{(data} \mathrm{taken} \mathrm{from} \mathrm{the} \mathrm{Fig.} \mathrm{1).} \mathrm{(a)} \mathrm{Kinetics} \mathrm{of} \mathrm{degradation} \mathrm{of} \mathrm{total} \mathrm{protein.}(b)$ Degradation of the labile fraction.

Table 3. Influence of temperature on the size of the labile protein fraction and the degradation constants of the labile and 'stable' fractions

The symbols are defined in Table 1. The data are taken from Fig. 3.

\begin{tabular}{|c|c|c|c|c|c|c|c|c|}
\hline \multirow{2}{*}{$\begin{array}{c}\text { Temp. } \\
\left({ }^{\circ} \mathrm{C}\right)\end{array}$} & \multirow{2}{*}{$\begin{array}{c}\text { Mass } \\
\text { doubling } \\
\text { time (h) }\end{array}$} & \multicolumn{4}{|c|}{ Labile fraction } & \multicolumn{3}{|c|}{ 'Stable' fraction } \\
\hline & & $L(\%)$ & $a_{1}\left(\mathrm{~h}^{-1}\right)$ & $r^{2}$ & $t_{\frac{1}{2}}(\mathrm{~h})$ & $a_{2}\left(\mathrm{~h}^{-1}\right)$ & $r^{2}$ & $t_{\frac{1}{2}}(\mathrm{~h})$ \\
\hline $\begin{array}{l}28 \\
35 \\
42\end{array}$ & $\begin{array}{l}1.9 \\
1.6 \\
1.4\end{array}$ & $\begin{array}{l}0.8 \\
1.5 \\
7.4\end{array}$ & $\begin{array}{l}1 \cdot 2 \\
1 \cdot 3 \\
1.4\end{array}$ & $\begin{array}{l}0.90 \\
0.86 \\
0.98\end{array}$ & $\begin{array}{l}0.58 \\
0.53 \\
0.50\end{array}$ & $\begin{array}{l}0.5 \times 10^{-2} \\
1.1 \times 10^{-2} \\
1.1 \times 10^{-2}\end{array}$ & $\begin{array}{l}0.94 \\
0.97 \\
0.95\end{array}$ & $\begin{array}{r}139 \\
63 \\
63\end{array}$ \\
\hline $\begin{array}{c}\text { Temp. } \\
\left({ }^{\circ} \mathrm{C}\right)\end{array}$ & $\begin{array}{r}\text { Autoproteo } \\
(3 \mathrm{~h}) \\
(\%)\end{array}$ & & $\begin{array}{l}\text { radation } \\
\text { ivo }(3 \mathrm{~h}) \\
(\%)\end{array}$ & & & & & \\
\hline $\begin{array}{l}28 \\
35 \\
42\end{array}$ & $\begin{array}{r}4 \cdot 3 \\
6 \cdot 9 \\
12.9\end{array}$ & & $\begin{array}{r}2 \cdot 4 \\
4 \cdot 7 \\
10 \cdot 3\end{array}$ & & & & & \\
\hline
\end{tabular}

We deduce that the main target of the regulation of protein turnover is the size of the pool of labile proteins. The regulation of degradation of the 'stable' fraction seems to be of only minor importance.

The fact that the size of the labile protein fraction was regulated by the medium in which the prelabelled cells were grown, indicates that this fraction is not composed only of abnormal proteins or proteins undergoing processing. Some groups of proteins are probably degraded preferentially as the 'labile' fraction, because after this ${ }^{14} \mathrm{C}$-labelled fraction had been degraded during starvation it could only be partially restored by a combination of shift-up and shift-down treatments (Chaloupka \& Strnadová, 1980). The existence of some proteins with short half-lives was detected in growing $E$. coli by two-dimensional electrophoresis (Mosteller et al., 1980; Larrabee et al., 1980). However, it seems reasonable to suppose that 
at least some proteins degraded as 'labile' proteins can be found in the fraction which is relatively stable under other conditions, as the size of the fraction of labile proteins is influenced by subsequent cultivation.

Degradation of the residual proteins (degradation of the 'stable' fraction) might be due only to the basal activity of intracellular proteinase, whose activity in vitro corresponds approximately to the degradation rate of the 'stable' fraction in vivo (Váchová-Philippová \& Chaloupka, 1978).

\section{REFERENCES}

BukHARI, A. I. \& ZIPSER, D. (1973). Mutants of Escherichia coli with a defect in the degradation of nonsense fragments. Nature New Biology 243, 238-241.

Chaloupka, J. \& Strnadová, M. (1980). Degradation and replenishment of the labile protein fraction in non-growing cells of the asporogenic mutant of Bacillus megaterium. Folia microbiologica 25, 191200.

Chaloupka, J., ObdržÁlek, V., KŘEčKová, P., Nesmeyanova, M. A. \& ZalabÁK, V. (1975). Protease activity in cells of Bacillus megaterium during derepression. Folia microbiologica 20, 277288.

GoldBERG, A. L. (1972). Degradation of abnormal proteins in Escherichia coli. Proceedings of the National Academy of Sciences of the United States of America 69, 422-426.

Goldberg, A. L. \& St John, A. C. (1976). Intracellular protein degradation in mammalian and bacterial cells: Part 2. Annual Review of Biochemistry 45, 747-803.

Larrabee, K. L., Phillips, J. O., Williams, G. J. \& LARREBEE, A. R. (1980). The relative rates of protein synthesis and degradation in growing culture of Escherichia coli. Journal of Biological Chemistry 255, 4125-4130.

Mosteller, R. D., Goldstein, R. V. \& Nishimoto, K. R. (1980). Metabolism of individual proteins in exponentially growing Escherichia coli. Journal of Biological Chemistry 255, 2524-2532.
NATH, K. \& Koch, A. L. (1970). Protein degradation in Escherichia coli. I. Measurement of rapidly and slowly decaying components. Journal of Biological Chemistry 245, 2889-2900.

PiNe, M. J. (1970). Steady-state measurement of the turnover of amino acid in the cellular proteins of growing Escherichia coli: existence of two kinetically distinct reactions. Journal of Bacteriology 103, 207-215.

Pine, M. J. (1973). Regulation of intracellular proteolysis in Escherichia coli. Journal of Bacteriology 115, 107-116.

Setlow, P. (1975). Protein metabolism during germination of Bacillus megaterium spores. II. Degradation of pre-existing and newly synthesized protein. Journal of Biological Chemistry 250, 631-637.

VÁchová-Philippová, L. \& Chaloupka, J. (1978). Degradation of proteins in vivo and in vitro in exocellular proteinase deficient mutants of Bacillus megaterium. FEMS Microbiology Letters 4, 117120 .

VÁchová-PhilipPovÁ, L., Strnadová, M. \& ChaloupKa, J. (1980). Turnover of proteins in asporogenic Bacillus megaterium. Evidence for a gradual decrease of the turnover rate. Folia microbiologica 25, 185-190.

Yoshida, A. \& YAMASAKI, M. (1959). Studies on the mechanism of protein synthesis. Incorporation of ethionine into $\alpha$-amylase of Bacillus subtilis. Biochimica et biophysica acta 34, 158-165. 